Research Article

Bojiang Fan, Liang Shi*, Yating Li, Tianjing Zhang, Lei Lv, and Tong Shikai

\title{
Lithologic heterogeneity of lacustrine shale and its geological significance for shale hydrocarbon-a case study of Zhangjiatan Shale
}

https://doi.org/10.1515/geo-2019-0009

Received Jul 03, 2018; accepted Oct 13, 2018

\begin{abstract}
The Zhangjiatan shale of the Southeastern Ordos Basin, which deposits in deep lake facies, has strong lithologic heterogeneity; it represents as shale, sandy laminae shale and thin sandstone. Shale with $\mathrm{mm}$ - to $\mathrm{cm}$-scale sandy laminae is defined as Sandy Laminae Shale (SLS). However, the relationship between lithologic heterogeneity and hydrocarbon accumulation has never been studied. This study shows that lithologic heterogeneity, especially the occurrence of SLS will influence the accumulation of hydrocarbons within the shale system. SLS commonly has a larger pore size, higher porosity and better connectivity than thick and homogeneous shale. SLS commonly contains fewer residual hydrocarbons than homogeneous thick shale, indicating comparative ease in hydrocarbon expulsion. SLS commonly generates more bedding fractures. More fractures can be incurred when fracture extending into SLS. The occurrence of SLS can provide more storage spaces for fluids and gases, including oil, water, adsorbed gas, dissolved gas and free gas. SLS has been the pilot exploration and development target for shale hydrocarbon in the southeastern Ordos Basin. Homogeneous and thick shales, which have a large content of residual hydrocarbons, would be the targets for future exploration.
\end{abstract}

Keywords: SLS, Hydrocarbon distribution, Shale hydrocarbon, Zhangjiatan Shale, Southeastern Ordos Basin

\footnotetext{
^Corresponding Author: Liang Shi: School of Petroleum and

*Corresponding Author: Liang Shi: School of Petroleum and
Environmental Engineering, Yan An university, Yan An 716000, China; Email: 459942621@qq.com; Tel.: +86 18629551885 China; Email: 459942621@qq.com; Tel.: +86 18629551885 School of Petroleum and Environmental Engineering, Yan An university, Yan An 716000, China
}

¿ Open Access. (c) 2019 B. Fan et al., published by De Gruyter. (Cc) BY License

\section{Introduction}

Deep lake facies don't always comprise of pure mudstone or shale within the quiet water environment, they may develop sandy laminae or thin sandstone which indicates a more complex geological process [1, 2]. Sandy Laminae Shale (SLS) (shale with $\mathrm{mm}$ - to $\mathrm{cm}$-scale sandy lamina) has been identified in deep-lacustrine mudstone depositional facies in many hydrocarbon prosperous basins in China (e.g., Ordos Basin, Qaidam Basin, Junggar Basin and Bohai Bay Basin) [3]. However, sandy lamina shale has been largely ignored because it is regarded as a secondar reservoirs compared with pure sandstone, which has a relatively higher porosity and permeability.

Under the background of the boost of the shale hydrocarbon industry, homogeneous and thick shale have been the sweet spots for shale gas exploration and development [4]. Meanwhile, shale with lamina aroused researchers' attention [3,5]. Although sedimentary laminae have been widely used for paleogeographic reconstruction and interpreting the physical, chemical and biological processes during sediment deposition, only a few previous studies focused on sandy lamina shale [6-8].

Sandy lamina shale has higher porosity and permeability than pure shale above and below, and sandy laminae provide a significant reservoir and also act as an important hydrocarbon migration route $[9,10]$. The development of sandy laminae increases the rock brittleness and thus favors the development of fractures [11]. The fracturing capacity correlates positively with the abundance of sandy laminae in mudstone or shale facies [12, 13]. In the Southeastern Ordos Basin, there is a linear relationship between the layers of sandy laminae and the total thickness of sandy laminae within the Ordos Basin, and the development of sandy laminae helps to improve the physical properties of shale reservoirs $[5,8]$. It has been reported that in areas where there is an abundance of sandy laminae, it correlates positively with shale-gas productivity [14]. previous researches peculated that sandy laminae developed in Southeastern Ordos Basin belongs to sandy clastic flow 
deposits [15]. However, the influence of sandy laminae on shale hydrocarbon accumulation has not been studied in literature.

\section{Geological setting}

The Ordos Basin, located in the western part of China, has an area of $37 \times 10^{4} \mathrm{~km}^{2}$ and is the second largest sedimentary basin in China. The basin is bounded by the Liupanshan Basin on the west, the Qilian-Qinling zone on the southwest, the Luliang Uplift on the east, the Hetao Graben on the north, the Fenwei Graben on the south, and the Alashan Platform on the northwest. The Ordos Basin develops $5-18 \mathrm{~km}$ of sedimentary rocks overlying the Archaean basement [12, 16] (Figure 1). The intense tectonic movements during its geological history incurred many faults and foldings in the basin margins, while internally this basin is structurally stable (the sedimentary strata is just gently dipping). From Triassic to Cretaceous, the Ordos Basin deposits a series of fluvial-lacustrine systems. The Triassic fluvial-lacustrine system includes Yanchang Formation, Fuxian Formation, Yanan Formation, Zhiluo Formation and Anding Formation. The Cretaceous fluvial-lacustrine system includes Luohe-Yijun Formation, Huachi Formation, Huanhe Formation and LuohandongJingchuan Formation. From late Cretaceous to Cenozoic, the Ordos Basin undergoes a series uplifts and a large thickness of sediments are eroded.

The Upper Triassic Yanchang Formation contains ten lacustrine successions i.e. Chang 1 Member, Chang 2 Member, Chang 3 Member, Chang 4 Member, Chang 5 Member, Chang 6 Member, Chang 7 Member, Chang 8 Member, Chang 9 Member, and Chang 10 Member in descending order).

In the southeastern part of the basin, the Zhangiatan shale (it is the bottom part of Chang 7 Member of the Triassic Yanchang Formation) consists of organic-rich darkgrey and black shale [14] (Figure 2). Zhangjiatan shale is characterized by a large thickness (larger than $20 \mathrm{~m}$ and the largest thickness is almost $60 \mathrm{~m}$ within the southeastern part of the basin) and high total organic carbon content (3.5\% in average). After going through multiple tectonic events, they were buried in a shallow depth of 800 $1500 \mathrm{~m}$ and are rich in strawberry-shaped pyrites [14]. The Zhangjiatan shale is interpreted to have been deposited in a deep-lake environment and is laterally extensive and continuous, however, Zhangjiatan shale in the Southeastern Ordos Basin has strong lithologic heterogeneity, it represents deep-lacustrine deposits with abundant sandy laminae [14, 17].

Shale-gas exploration in the Triassic, Ordos Basin went through a major breakthrough in 2009 and great progress has been made since then. It has been gradually recognized that the organic-rich shale also contains sandy laminae of varying abundance [18].

\section{Sampling and Analytical Techniques}

More than 130 samples are used for this study, and most of them are collected from five wells i.e. YCYV1112, YCYV1120, YCYV1133, YCYV1113, YCCY1245. Multiple methods and techniques including core observation, logging judging, thin section observation, scanning electron microscope, $\mathrm{X}$ ray powder diffraction analysis, and geochemical analysis (Rock-Eval) are used in this study.

Thin section observation was conducted using a Polarizing microscope ( ${ }^{\star}$ BKK-POL); X-ray powder diffraction was conducted using XRD-BTX (Innov-X System); RockEvaluation was conducted using Rock-Eval-OG2000V. All the methods and techniques mentioned above are common and usual procedures without special treatment in this study.

\section{Characteristics of lithologic heterogeneity}

As the lithologic heterogeneity is mainly caused by the development of sandy laminae in the southeastern part of the Ordos Basin, this study is focused on the sandy laminae of the Zhangjiatan shale deposited in the deep-lake environment (Figure 3). They are mostly very thin ( $\mathrm{mm}$ - to $\mathrm{cm}$ scale, rarely in $\mathrm{m}$-scale) and are dispersed in the shale facies. In this study, the lithologic heterogeneity of Zhangjiatan shale represents the combination of shale, SLS and a few sandstone (most of them are decimeter scale).

\subsection{Lithologic difference}

The shale defined here is homogeneous pure shale, while shale with sandy laminae is defined as SLS. The lithologic characteristics of shale is as follows: (1) smooth broken surface (Figures 3A, B); (2) black color (Figures 3A, 3B, 3C); (3) relatively thick; (4) containing abundant small fossils 


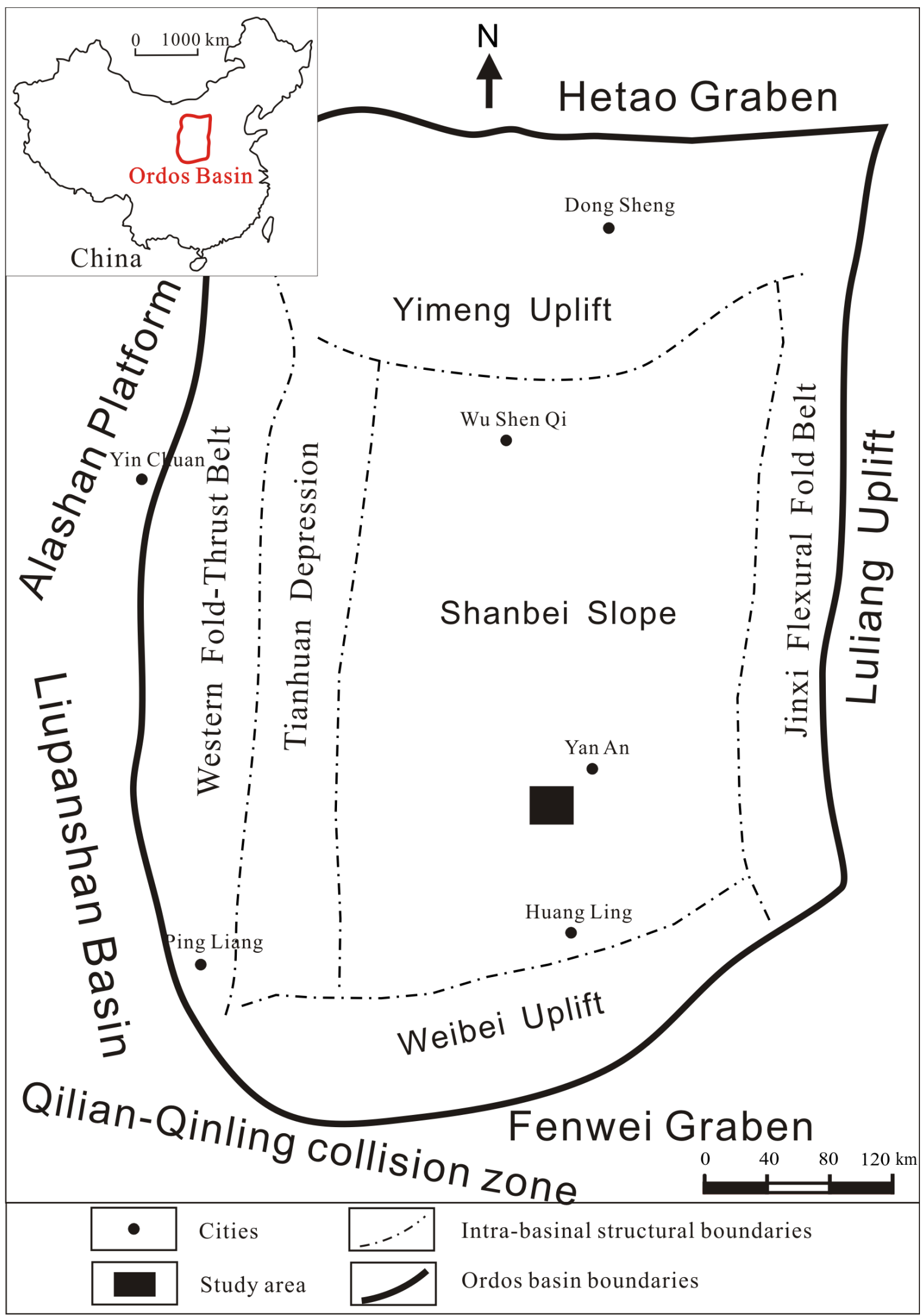

Figure 1: Map showing the tectonic units of the Ordos Basin and the location of the study area. 


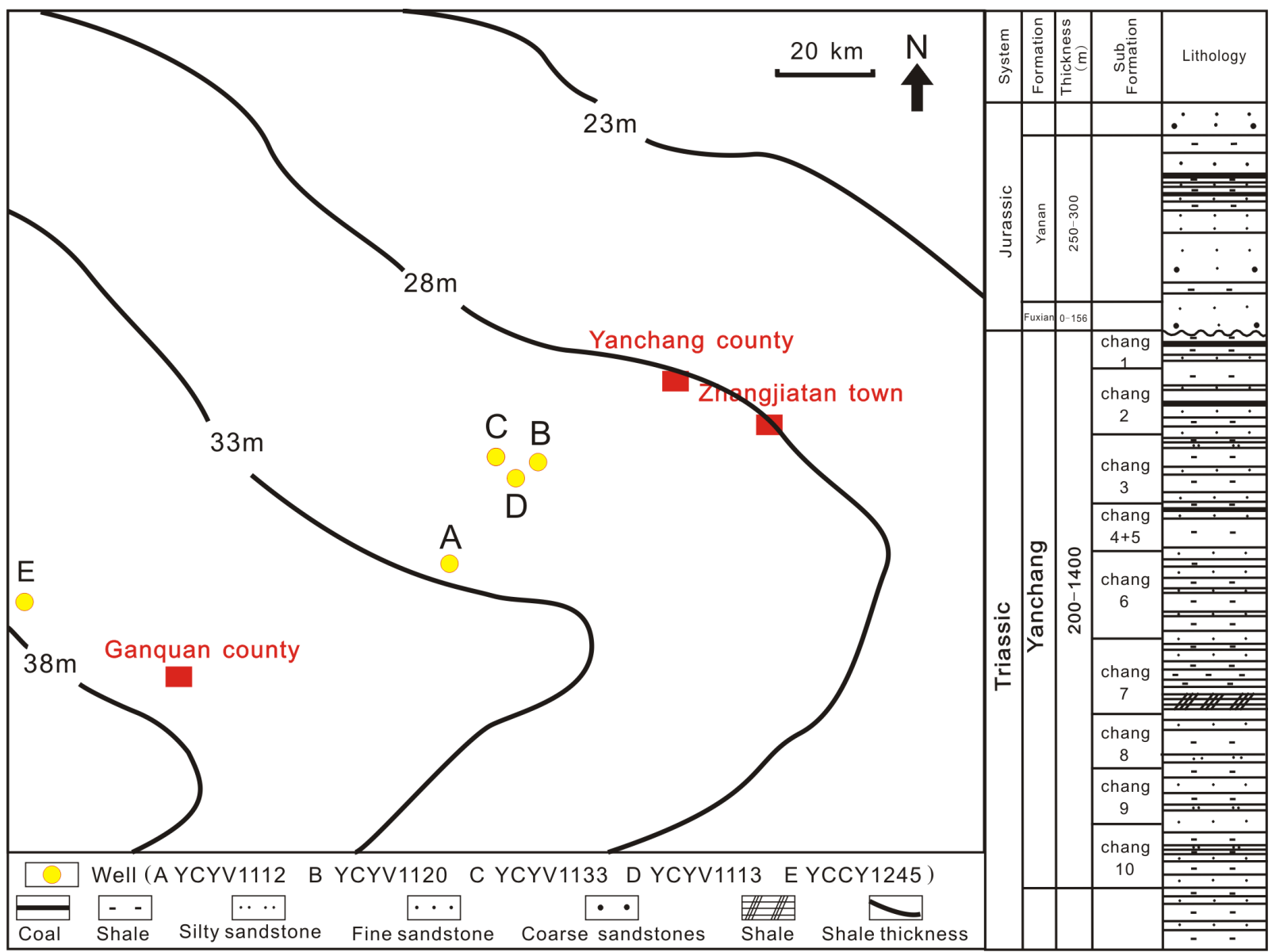

Figure 2: Map showing the thickness of Zhangjiatan shale and lithology of Yanchang FM.

(Figure 3K); and (5) containing nano to micron-meter scale pores (Figure 3I). SLS mainly consists of shale and siltstone (Figures 3D, 3E, 3F). It is commonly developed in the form of thin laminae and thin strips as observed under core observation and electron microscope (Figures 3D, 3E, 3F, 3G, 3H). The lithologic characteristics of SLS is as follows: (1) both shale and sandy laminae are extremely thin, most of them are millimeter scale (Figures 3D, 3E, 3F, 3G, 3H); (2) shale and sandy laminae interbedded each other like a "sandwich" framework (Figures 3D, 3E, 3F, 3G); (3) sandy laminae has light color; (4) the presence of more lamination fractures and large pores (e.g., large intergranular and intragranular pores) and (Figures 3J, 3L).

\subsection{Logging response}

According to the logging curves including SP, GR, AC and ILD in the study area, combined with core and microscopic characteristics, the lithologic combination of Zhangjiatan Shale can be divided into four sections, I, II, III, V and IV in the YCCV1245 well. As only a thickness of near 30m (Chang 7 member) of the YCCV1245 wells were cored, we judged the lithology from both cores and drilling cuts as well as the logging parameters. For this well, the cores were covered with sealing fluid and is very dirty, thus we had to split the core to get a view of shale and SLS (Figure 4). The five sections of lithologic combination represent five kinds of logging combination, respectively. SP and GR have a good response to the lithologic changes in the study area. In sandy layers, SP and GR show negative anomalies. In shale layers, SP and GR show positive anomalies. In sandy layered shale (most of them are SLS), SP and GR show "zigzag" characteristics (Figure 4). The changing characteristics of AC and ILD curves are more complex. As a whole, the AC value of shale is higher, and the AC value of SLS is lower. For example, B section is the combination of shale and SLS, and this section shows low $\mathrm{AC}$ values; $\mathrm{C}$ section, which has low AC values, is mainly shale, this may be caused by its high compaction during the geological time for this section is very tight. 

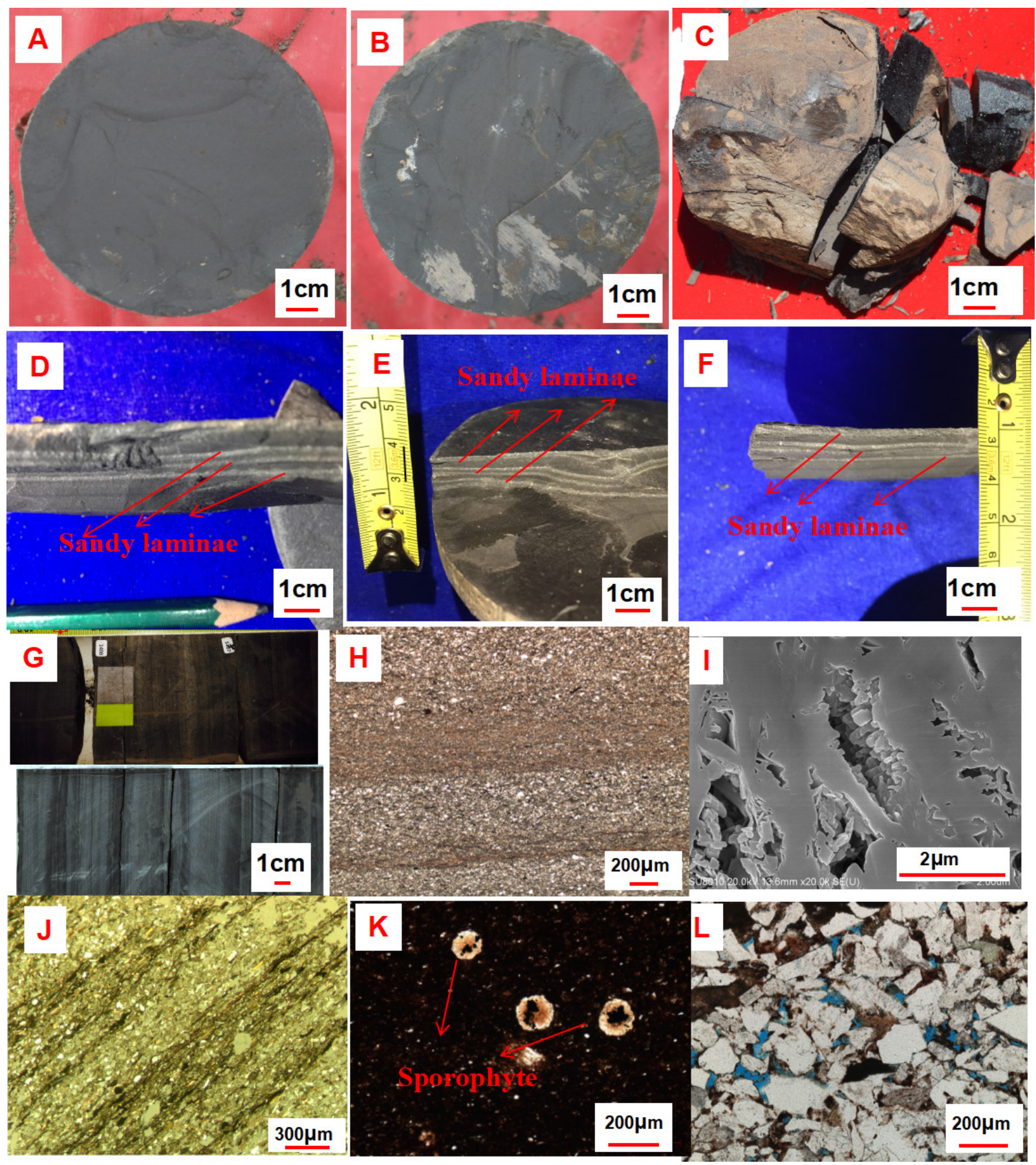

Figure 3: Characteristics of sandy laminae observed from core and thin sections:

(A) core sample of shale (well YCYV1112, 1322.1 m); (B) core sample of shale (well YCYV1112, 1348.4m); (C) core sample of shale filled by bitumen (well YCCY1245, 1525.7m); (D) core photo showing SLS (YCCV1245 well, $1554.4 \mathrm{~m}$ ); (E) core photo showing SLS (YCCV1252 well, $1388.4 \mathrm{~m}$ ); (F) core photo showing SLS (YCCV1245 well, $1561.6 \mathrm{~m}$ ); (G) sandy laminae in a shale core section (well YCYV1112, the upper part is near $1390.5 \mathrm{~m}$ and the lower part is near $1397.3 \mathrm{~m}$ ); (H) a thin section showing sandy laminae(well YCYV1120, 1497.8 m, single polarized light, 5×); (I) intragranular dissolution pores in shale (well YCYV1133, $1306 \mathrm{~m}$, SEM image, 20000×); (J) a thin section showing fractures developed in sandy laminae (well YCYV1113, $2513.3 \mathrm{~m}$, single polarized light, 5×); (K) cast thin section, single polarization (10X) showing a black shale with sporophyte (YCCV1245 well $1555.6 \mathrm{~m}$ ); (L) a thin section showing intergranular dissolution pores in sandy laminae (well YCCY1245, 1562.6m, single polarized light, 10×). 


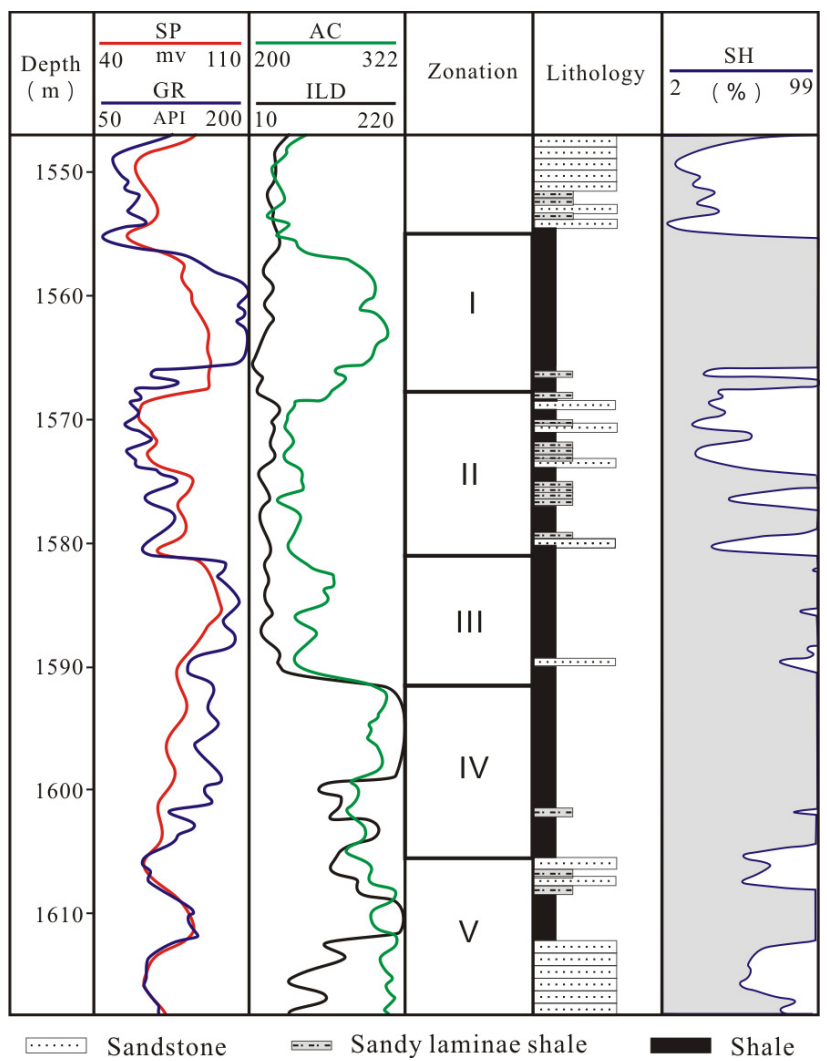

Figure 4: Logging characteristics of sandy laminae within Zhangjiatan Shale developed in the YCCV1245 well.

The ILD values of I section, II section and III section are lower, and the ILD values of IV and V sections are higher, which may be related to the content of the liquid hydrocarbon. IV and V sections commonly have higher content of liquid hydrocarbon (the oil smell can be smelled easily), and the content of liquid hydrocarbon in I, II and III sections is low (no oil smell can be smelled).

\subsection{Mineral compositions}

Sandy laminae within the SLS are characterized by a wide thickness ranges under microscope. X-ray powder diffraction analysis (XRD) indicates that the compositions of shale, SLS and sandstone are greatly different from each other. 12 SLS samples and 9 shale samples from the well YCCY1252 are analyzed in this study. For shale, quartz accounts for $22.5 \%-36.7 \%$ (28.6\% in average), feldspar accounts for $16.9 \%-35.5 \%$ (22.7\% in average) and clay minerals account for $33.7 \%-51.2 \%$ (44.2\% in average). For SLS, quartz accounts for $24.2 \%-43.6 \%$ (31.5\% in average), feldspar accounts for 26.1\%-55.3\% (38.6\% in average) and clay minerals account for $19.6 \%-41.4 \%$ (26.8\% in average).
In SLS, the matrix in between clastic grains can be divided into two groups: cement and clay minerals which can be syn-depositional or post-depositional. Due to intense compaction, syn-depositional clay minerals are commonly enclosed by irregular-shaped clastic grains. Cements are commonly characterized by quartz overgrowths. Samples of the sandy lamina shale in the study area consist mostly of irregular-shaped clastic grains, indicating syn-depositional origin. The SLS are locally fractured (Figures 3G, 3J).

\section{Discussions}

\subsection{Impact of lithologic heterogeneity on hydrocarbon conditions}

\section{(a) Liquid hydrocarbon distribution}

Different combination and contact patterns of rock lithology show different capabilities of hydrocarbon expulsion [19]. Some thick source rocks that are characterized by good hydrocarbon generation geochemical indicators (e.g., high TOC) show low efficiency in hydrocarbon expulsion [20]. Zhangiiatan Shale consists of high-quality shale, which has generated a large amount of hydrocarbon during its geological history [13]. Therefore, Rock-eval Pyrolysis Apparatus was used to analyze the content of free hydrocarbons in the rock (the content of liquid hydrocarbon in one unit mass rock under $300^{\circ} \mathrm{C}$ ). The shale mainly occurs between $1350-1470 \mathrm{~m}$ in the YCYV1112 well. Core logs show that it consists primarily of a thick shale unit above $1426 \mathrm{~m}$ and abundant SLS and thin sandstone (maximum thickness $<3 \mathrm{~m}$ ) below $1426 \mathrm{~m}$ (Figure 5) (the interval near $2570 \mathrm{~m}$ is another thick unit with few samples available for experiments due to samples missing). In general, free hydrocarbon content is higher in the thick shale unit than in the SLS and thin sandstone (Figure 5). It also increases with depth in the thick shale unit and then decreases getting close to the SLS unit (Figure 5). The reason for the variation and change is probably that hydrocarbon generated in the middle part of the thick shale unit is difficult to be expelled and transported away. SLS is interpreted to have made it more effective for hydrocarbon to be expelled and transported.

Free hydrocarbon content is relatively stable in the section below $1426 \mathrm{~m}$. Free hydrocarbon contents measured in the sandy laminate or thinly bedded sandstone and the shale layers are approximately the same (Figure 5). Since siltstone and sandstone are unable to generate hydrocar- 


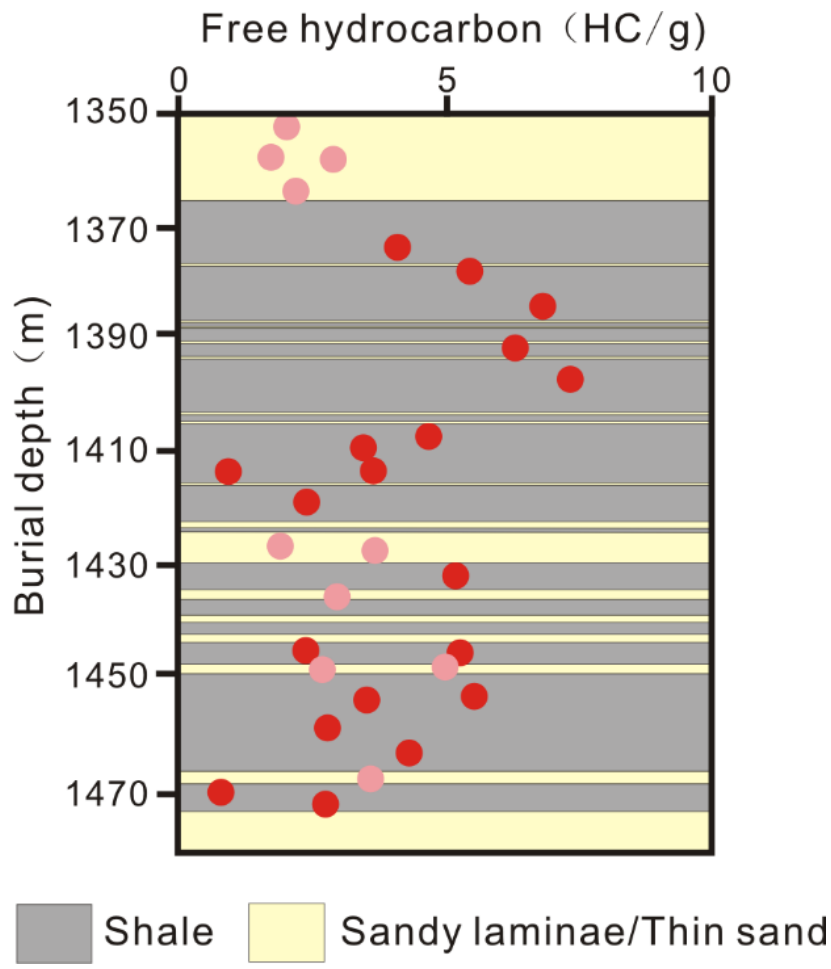

Figure 5: Cross plot showing the variation of free hydrocarbon content with burial depth change from $2480-2596 \mathrm{~m}$ in YCYV1112 well.

bons, they were probably migrated from overlying shale and underlying shale, which indicates that it is easier for hydrocarbons to migrate from SLS.

\section{(b) Hydrocarbon passages}

For Zhangjiatan shale, Both shale and SLS contain intergranular, intragranular and organic pores as observed under a microscope [18]. However, the abundance of pores and their connectivity are different. A higher percentage of intergranular and intragranular pores develop in SLS than in shale due to the higher content and larger grain size of quartz and feldspar (Figure 6). Compared to pores in shale, pore sizes are in average larger and connectivity is higher in SLS and thin sandstone. Shale, in contrast, consists of a higher content of organic matter and a higher percentage of organic pores [17]. Organic pores are more connected and laterally continuous in shale, but tend to be more isolated and limited in SLS and sandstone (Figure 6). However, the abundance of organic pores in shale varies significantly throughout the study area, which is interpreted to be closely related to the thermal maturity of the organic matter. Many studies have shown that organic matters with low thermal maturity are characterized by poor development of organic pores [21]. Other studies have also indicated that the occurrence and abundance of organic pores are affected by the type of organic matters. Terrestrial depositional systems (e.g., lacustrine) are characterized by a strong heterogeneity and quick lateral facies changes, which result in quick changes in organic pore types and thus the occurrence and abundance of organic pores [22].

Rock specific surface area and bulk porosity can be measured through $\mathrm{N}_{2}$ adsorption isotherm. The size distribution of micropores $(0.35-300 \mathrm{~nm})$ can be acquired by a combination of DFT (Density Functional Theory) and BJH (Barrett-Joyner-Halenda) methods [23-25]. Experimental results from the YCYV1112 well show that pore sizes predominantly range between 10-50 $\mathrm{nm}$ in SLS and 5-20 nm in shale (Figure 7) [25]. The predominant micropore sizes are obviously higher in SLS than in Homogenous Thick Shale (HTS). The reason for that is probably that SLS consists of a higher content of quartz and feldspar, which are characterized by high brittleness, favoring pore preservation [26]. The dissolution of quartz, feldspar and carbonate minerals also favors the development of pores and increase in porosity.

Using the nonsteady steady pulse decay method with a carrier gas of helium, The porosity and permeability of shale as well as SLS were tested. In the testing process, 45 shale samples and 51 SLS samples were used. The experimental results show that, the proportion of porosity ranging from $0.0 \%$ to $4.0 \%$ is $55.6 \%$ of the total samples for shale, the proportion of porosity ranging from $4.0 \%$ to $10.0 \%$ is $44.4 \%$ of the total samples for shale; the proportion of porosity ranging from $0.0 \%$ to $4.0 \%$ is $41.2 \%$ of the total samples for SLS, the proportion of porosity ranging from $4.0 \%$ to $10.0 \%$ is $58.8 \%$ of the total samples for SLS (Figure 8). This phenomenon indicates that, the porosity of SLS is higher than that of shale. The permeability also shows the same distribution trend as that of porosity, indicating the higher permeability of SLS (Figure 8).

\section{(c) Fracture development}

Rocks of different lithology are characterized by different mechanic properties. The occurrence of sandy laminae in shale changed the mechanic properties locally and affected the degree of the development of fractures. The study area has been through multi-phase tectonic movements including Yanshan and Himalaya Movements [27], which have resulted in abundant extensional fractures. Distinctive differences are identified between SLS and shale in their fracture characteristics. Fractures developed 

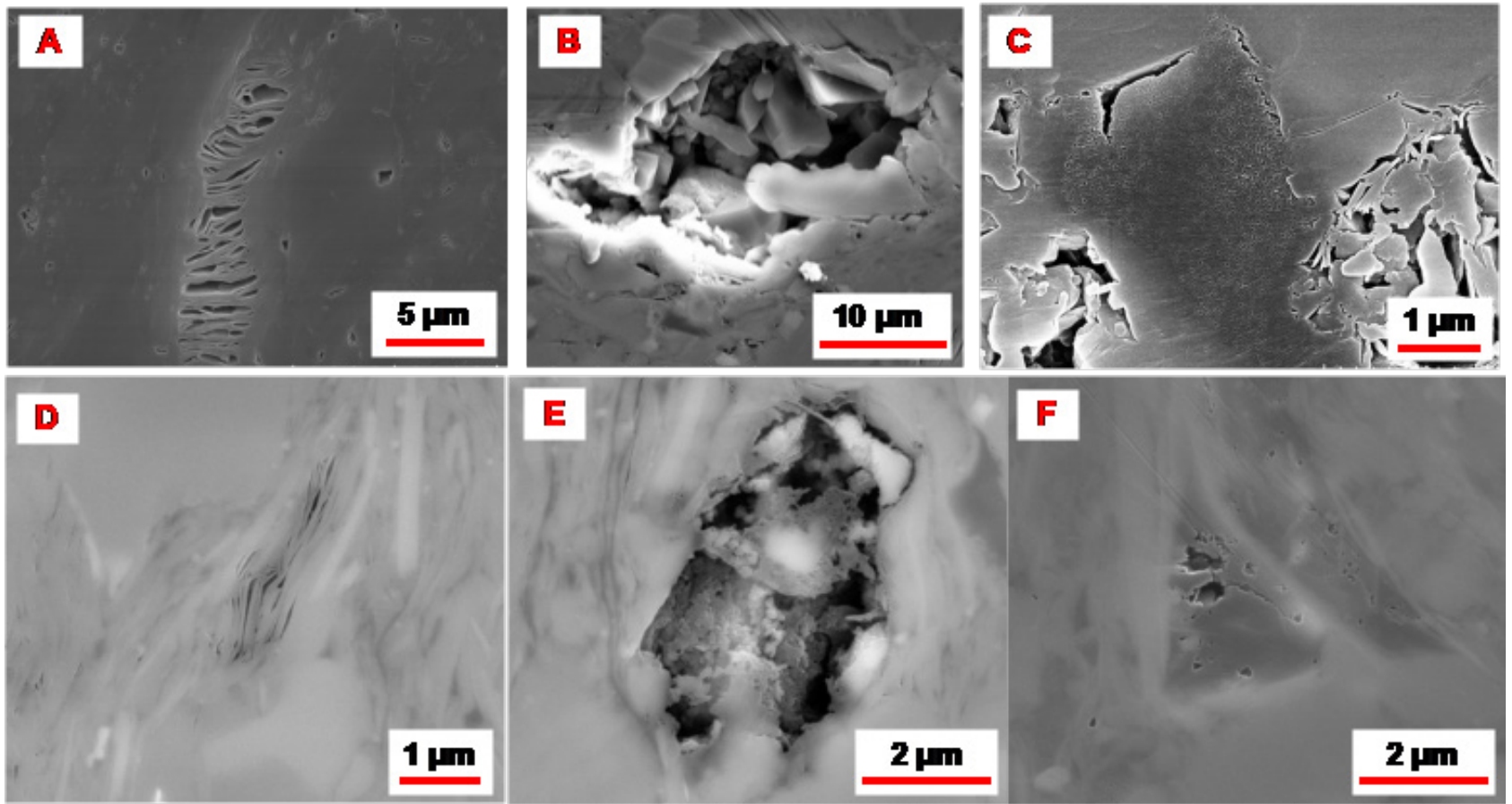

F

Figure 6: SEM images showing pore development of shale \& SLS

(A) organic pores developed within clay minerals, SLS (YCYV1133 well, $1340 \mathrm{~m}, 5000 \mathrm{X}$ ); (B) intragranular pores filled with autogenic quartz, SLS (YCYV1112 well, $1397.66 \mathrm{~m}, 9000 \mathrm{X})$; (C) organic pores and intergranular pores developed within organic matter, SLS (YCYV1122 well, $1163 \mathrm{~m}, 20000 \mathrm{X}$ ); (D) organic pores developed within clay minerals, shale (YCYV1112 well, $1414 \mathrm{~m}, 50000 \mathrm{X}$ ); (E) intragranular pores developed within clay minerals, shale (YCYV1112 well, $1414 \mathrm{~m}, 40000 \mathrm{X})$; (F) organic pores developed within organic matter, shale (YCYV1112 well, 1504.98 m, 40000X).
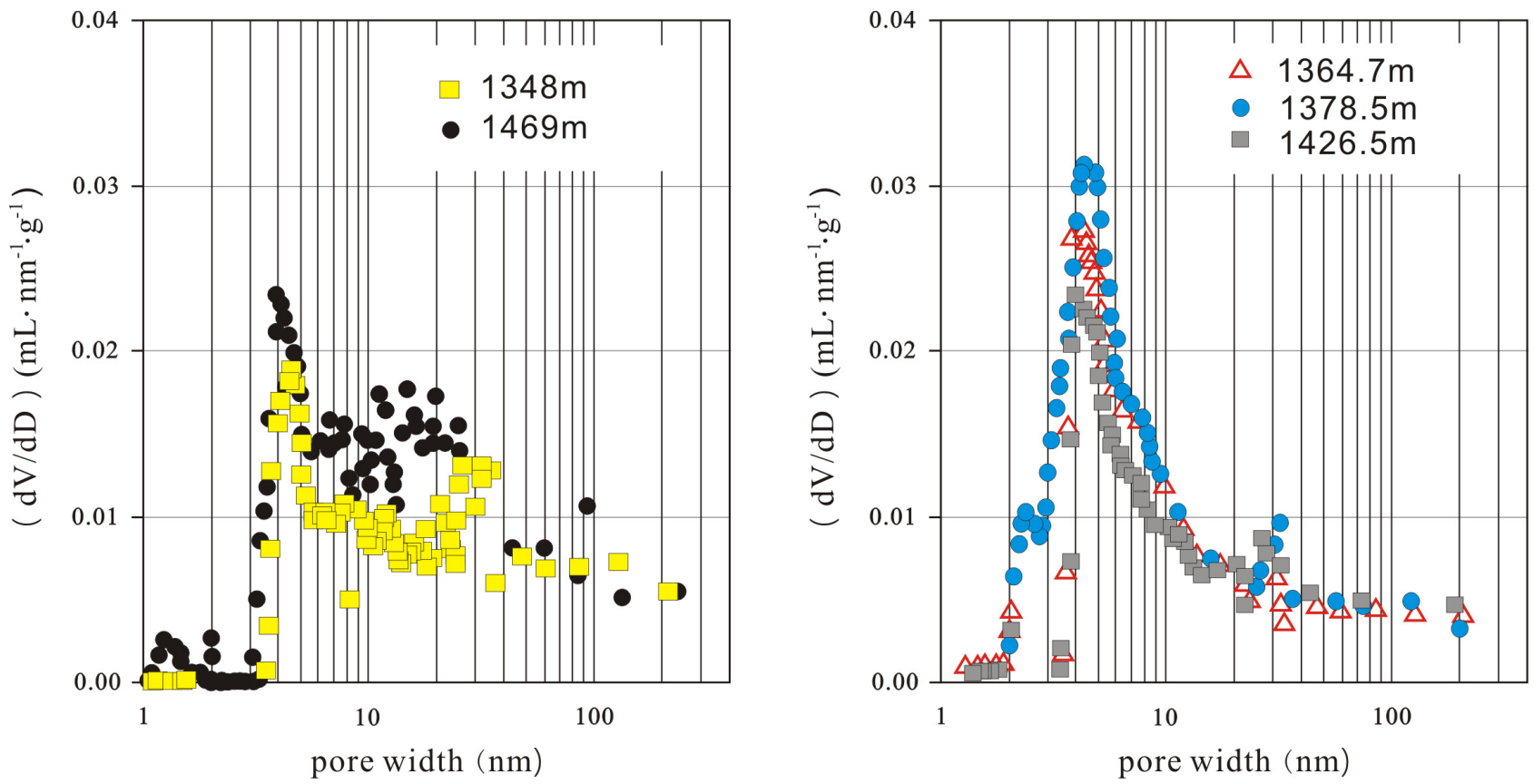

Figure 7: Scatter plot showing the distribution of SLS (left) and shale (right) in the YCYV1112 well. 

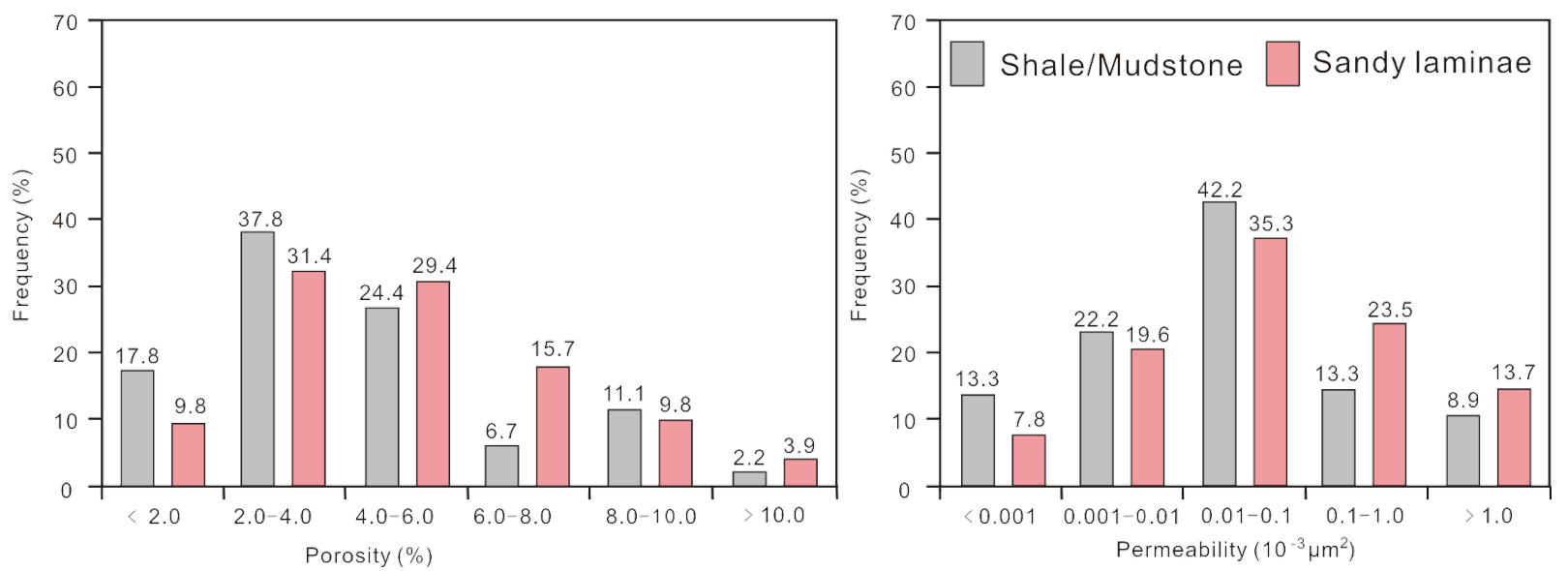

Figure 8: Histogram showing porosity and permeability of shale \& SLS.
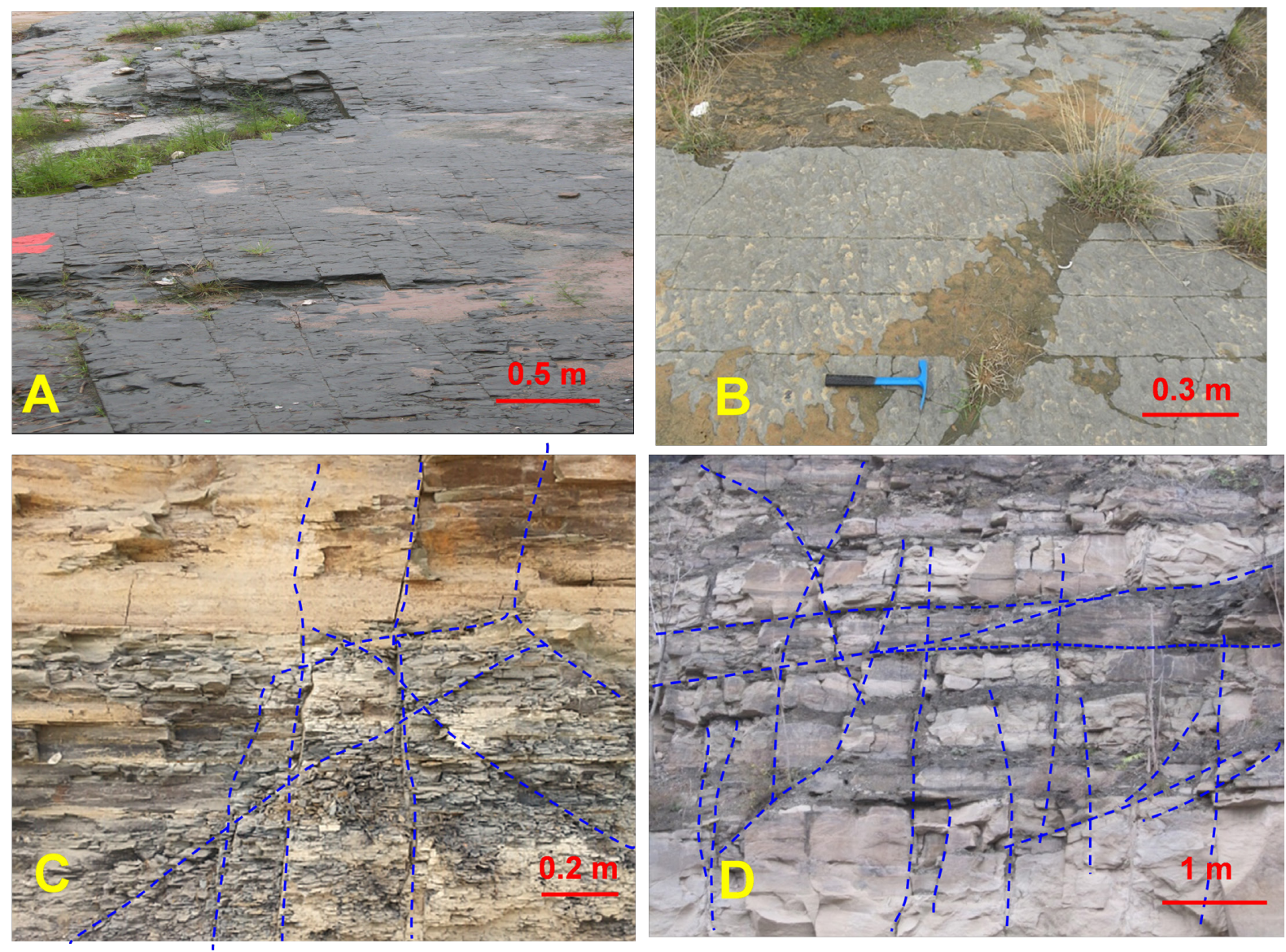

Figure 9: Outcrop images showing fractures in Zhangjiatan Shale (A, B fractures in plan-view, outcrops located $11 \mathrm{~km}$ southeast of the Yanchang County; $C$ fractures in cross section view, outcrops located $11 \mathrm{~km}$ southeast of the Yanchang County; D fractures in cross section view, outcrop located $75 \mathrm{~km}$ east of the Fuxian County).

in SLS disperse or refract when they extend into homogeneous thick shale, increasing their fracture density. In contrast, fracture density decreases when they cut through shale and extend into rocks of different lithology (Figure 9).
SLS developed under a stronger hydrodynamic depositional background than shale. The contact surface between sandy laminae and shale is mechanically weak and susceptible to fracturing [28]. Consequently, the occurrence of sandy laminae leads to the development of 
interlayer fractures. Most fractures in sandy laminated shale develop along laminations. Some of the fractures are filled with bitumen and thus show fluorescence, indicating the occurrence of hydrocarbon primary migration in the SLS. In addition, the fractures in SLS are characterized by longer lengths than in HTS and thus are more effective in enhancing reservoir permeability. Locally, fractures form grid networks (Figures 9), which is interpreted to have been caused by the strong heterogeneity resulted from the development of sandy laminae. Fractures can be routes for hydrocarbon migration and provide spaces for hydrocarbon storage. The development of fractures as favored by the occurrence of sandy laminae have changed the hydrocarbon migration route and special distribution in a positive way.

\subsection{Hydrocarbon hosting states}

For the low maturity Zhangjiatan Shale, there are oil, gas and water co-existing within the shale system, and the hydrocarbon gases occur in three states: adsorbed gas, free gas and dissolved gas (in oil and water) (Figure 10). Adsorbed gases are attached to the surface of organic matter, kerogen and clay minerals by van der Waals' force. Free gases occur and move freely in pores and fractures. Dissolved gases exist in liquid oil and water. Zhangjiatan shale, which contains predominantly Type II kerogen and has an average TOC of $3.3 \%$ and clay mineral up to $44.2 \%$,

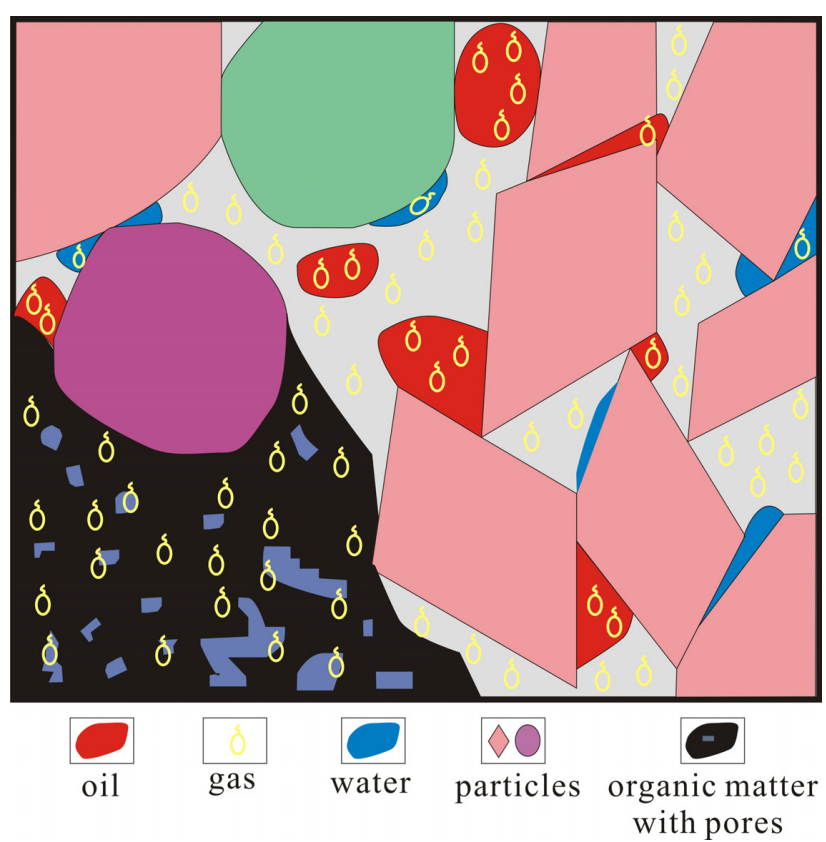

Figure 10: Conception model showing oil, gas and water co-existing within the shale system. is characterized by strong adsorption capacity and capability. Isothermal adsorption experiments of four samples containing SLS under formation pressure (5.2 MPa) indicate an average adsorption capacity of $2.8 \mathrm{~m}^{3} / \mathrm{t}$ (Figure 11 ). Due to the layered adsorption of hydrocarbon gases in organic-rich shale, micro-scale pores and fractures are easily filled with adsorbed gases. Adsorbed gases account for a high percentage of the total volume of shale gas.

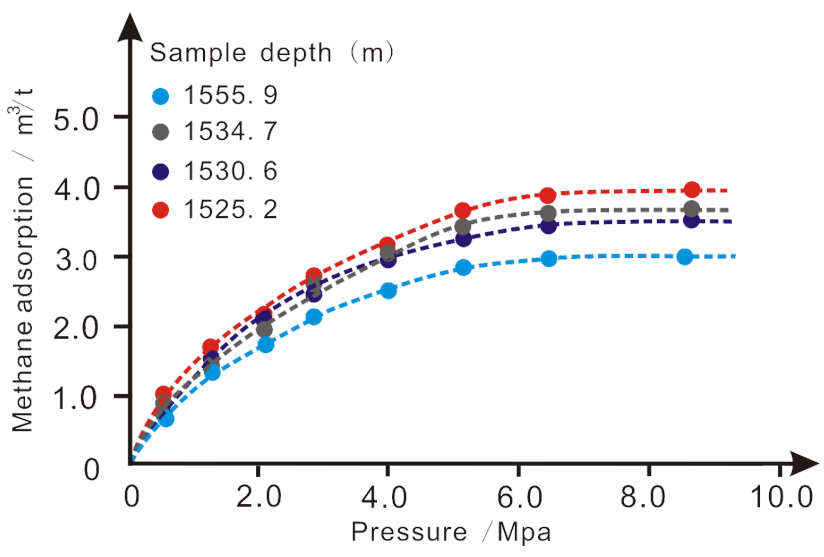

Figure 11: Plot showing the result of isothermal adsorption experiments (four samples from the YCCY1245 Well, SLS).

SLS is characterized by very low adsorption capability compared with shale, because of the high content of quartz and feldspars and low content of organic matter and clay mineral. Its higher porosity and natural fractures, however provide more storage space for hydrocarbons. Six shale samples containing SLS from the YCCY1245 Well have an average oil saturation of $39 \%$, an average water saturation of $34 \%$ and an average gas saturation of $27 \%$ (free gas). The amount of dissolved gas can be calculated based on equations as follows:

$$
\begin{gathered}
G_{d}=G_{o}+G_{w} \\
G_{o}=\frac{C_{0}}{1000 \times \rho_{o}} \times R_{o g} \\
G_{w}=\frac{C_{w}}{1000 \times \rho_{w}} \times R_{w g}
\end{gathered}
$$

$G_{d}$ : content of dissolved gas, $\mathrm{m}^{3} / \mathrm{t} ; G_{o}$ : content of dissolved gas in oil, $\mathrm{m}^{3} / \mathrm{t} ; G_{w}$ : content of dissolved gas in water, $\mathrm{m}^{3} / \mathrm{t} ; R_{o g}$ : Solubility of gas in oil, $\mathrm{m}^{3} / \mathrm{m}^{3} ; R_{w g}$ : Solubility of gas in water, $\mathrm{m}^{3} / \mathrm{m}^{3} ; \rho_{o}$ : oil density, $\mathrm{g} / \mathrm{cm}^{3} ; \rho_{w}$ : water density, $\mathrm{g} / \mathrm{cm}^{3} ; C_{0}$ : oil content of samples, $\mathrm{mg} / \mathrm{g} ; C_{w}$ : water content of samples, $\mathrm{mg} / \mathrm{g}$.

The content of free gas within Zhangjiatan shale can be calculated using a PVT equation (P represents pressure, 
$\mathrm{V}$ represents volume, and $\mathrm{T}$ represents temperature). The equations are as follows:

$$
\begin{gathered}
G_{f}=B_{g} \frac{\phi \times S_{g}}{\rho_{T}} \\
S_{g}=1-S_{w}-S_{o}
\end{gathered}
$$

$G_{f}$ : content of free gas, $\mathrm{m}^{3} / \mathrm{t} ; \Phi$ : total porosity, $\% ; S_{g}$ : gas saturation, $\% ; \rho_{r}$ : density of rock sample, $\mathrm{t} / \mathrm{m}^{3} ; B_{g}$ : volume coefficient; $S_{w}$ : water saturation, $\% ; S_{o}$ : oil saturation.

Using the equations above, the calculation result of the six shale samples contaning SLS shows that dissolved gas content ranges $0.28-1.25 \mathrm{~m}^{3} / \mathrm{t}$ (average $0.44 \mathrm{~m}^{3} / \mathrm{t}$ ) and free gas range contents ranges $0.42-1.36 \mathrm{~m}^{3} / \mathrm{t}$ (average 0.95 $\mathrm{m}^{3} / \mathrm{t}$ ). This indicates that a higher amount of free and dissolved gas occurs in shale containing sandy laminae.

\subsection{Implications for shale gas exploration}

From the perspective of shale hydrocarbon exploration, deep-lake thick shale would make the favorable prospect. However, exploration results in the study area indicate that exploration wells drilled in SLS show better performance than wells targeting HTS. The fact that deep-lake homogenous shale is not as productive as sandy laminated shale could be explained from three aspects by looking at the regional geological background in the study area. (1) The Zhangjiatan Shale is characterized by extremely low permeability and abnormally low formation pressure (formation pressure to hydrostatic pressure ratio of 0.5-0.7) $[13,18]$, which results in a slow return of the fracturing fluid, a higher possibility of formation damage and the closing of hydraulic fractures during and after fracturing. (2) Comparatively low thermal maturity in the study area (still in the oil window) $[13,18]$. A large quantity of water as well as gas exists in the shale reservoir, which make it difficult to drain all the fracturing fluids and impede the hydrocarbon flow in the shale reservoir and thus production performance (Figure 12). (3) The Formation temperature is very low, with an averrage of $\left.50-60^{\circ} \mathrm{C}\right)[13,16,18]$. Shalegas desorption is difficult and not effective under the reservoir's temperature condition, resulting in low gas productivity. In addition, the hydrocarbon development in thick shale formations also faces other challenges including low wellbore stability due to high clay-mineral content and difficulty in controlling well tracks during drilling.

Consequently, the most promising hydrocarbon exploration and development prospects in deep lacustrine environments in Zhangjiatan Shale are those containing sandy

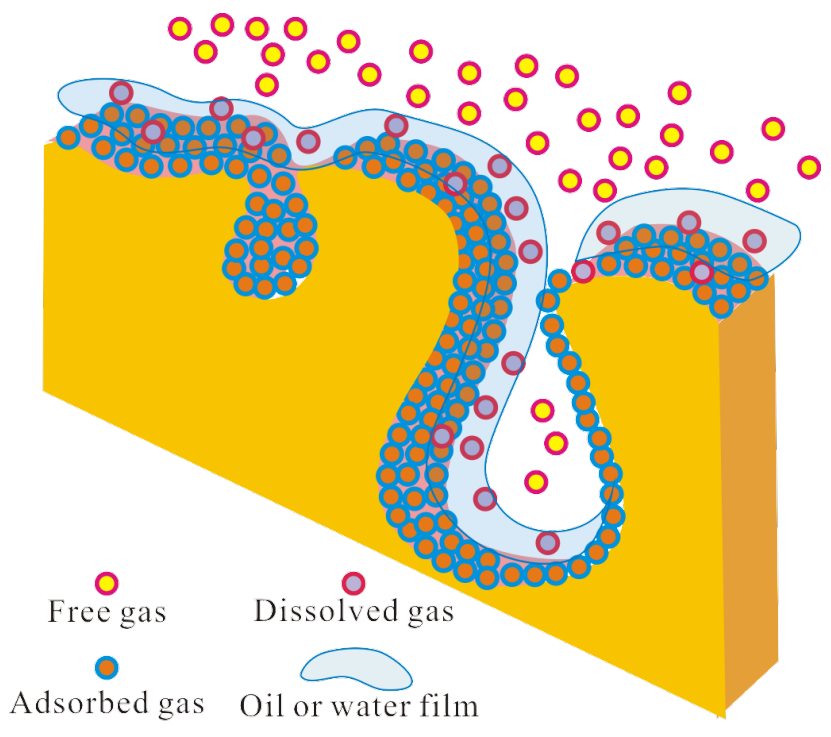

Figure 12: Hosting model of oil, gas and water within the shale pore system.

laminated shale. Even though there are great hydrocarbon potentials in HTS, effective development will require techniques and breakthroughs in developing low permeability, low temperature and pressure and low thermal maturity reservoirs.

\section{Conclusions}

The Zhangjiatan shale of Southeastern Ordos Basin has strong lithologic heterogeneity, it represents as shale, SLS and thin sandstone. SLS commonly has a larger pore size, higher porosity and better connectivity than thick and homogeneous shale.

SLS commonly contains fewer residual hydrocarbons than homogeneous thick shale, indicating comparative ease in hydrocarbon expulsion. SLS commonly generates more bedding fractures. More fractures can be incurred when fracture extending into SLS.

SLS in the southeastern part of the Ordos Basin is the main exploration targets for shale hydrocarbons at present. Thick deep-lacustrine shale, which contains huge hydrocarbon potential, however would be a future target due to limitations in development techniques.

Acknowledgement: This work was financially supported by National Natural Science Foundations of China (Grant No. 41702136), Special Project of Shaanxi Province Education Department (Grant No. 19JK0872). 


\section{References}

[1] Spears, D.A., Lundegard, P.D., Samuels, N.D., Field classification of fine-grained sedimentary rocks; discussion and reply. Journal of Sedimentary Research, 1980, 51, 1031-1033.

[2] Spears, D.A., Towards a classification of shales. Journal of the Geological Society, 1980, 137, 125-129.

[3] Sheng, X., Chen, X., Zhang, X., et al. Prospects and challenges of continental shale oil development in China. Petroleum Geology \& Experiment, 2015, 37, 267-271 (in Chinese with English abstract).

[4] Ryder, R.T., Burruss, R.C., Hatch, J.R.,Black shale source rocks and oil generation in the Cambrian and Ordovician of the central Appalachian Basin, USA. AAPG Bulletin, 1998, 82, 412-441.

[5] Cheng, M., Luo, X.R., Lei, Y.H., et al. The Distribution, Fractal Characteristic and Thickness Estimation of Silty Laminae and Beds in the Zhangjiatan Shale, Ordos Basin. Natural Gas Geoscience, 2015, 26, 845-852.

[6] Chu, G., Liu, J., Liu, D., Discrimination of two kinds of sedimentary laminae in maar lakes of China. Chinese Science Bulletin, 2000, 45, 2292-2295.

[7] Pilskaln, $\mathrm{CH}$., Pike, J., Formation of Holocene sedimentary laminae in the Black Sea and the role of the benthic flocculent layer. Paleoceanography, 2001, 16, 1-19.

[8] Yang, X., Jiang, C.F., Sun, B.H. et al. Development characteristics of sandy laminae and their effects on physical properties of shale reservoirs: a case study of the Mesozoic Yanchang Formation in the southern Ordos Basin. Journal Yan An University(Natural Science Edition), 2015, 34, 18-23.

[9] Blažauskas, N., Jurgaitis, A., Šinkūnas, P., Sedimentation of Quaternary sandy deposits in South Lithuania. Lithosphere, 1998, 2, 87-100.

[10] Estrada, S., Piepjohn, K., Henjes-Kunst, F., et al. Geology, Magmatism and Structural Evolution of the Yelverton Bay Area, Northern Ellesmere Island, Arctic Canada. Polarforschung, 2006, 73, 5975.

[11] Tipper, J.C., Sach, V.J., Heizmann, E.P.J., Loading fractures and Liesegang laminae: new sedimentary structures found in the north-western North Alpine Foreland Basin (Oligocene- Miocene, south-west Germany). Sedimentology, 2010, 50, 791-813.

[12] Fan, B., Oil reserve of Chang7 Shale, Triassic Yanchang Formation, Ordos Basin. Petroleum Science \& Technology, 2017, 35, 789794.

[13] Fan, B., Wang, X., Wu, X., et al. Desorption analysis of shale and its geochemical characteristics:A case study of the Chang 7 member shale in the central south Ordos basin. Journal of China University of Mining \& Technology, 2017, 46, 554-562.

[14] Wang, X., Zhang, L., Chao, G., The Heterogeneity of Lacustrine Shale Gas Reservoir in Yanchang Formation, Xiasiwan Area, Ordos Basin. Acta Geologica Sinica (English Edition), 2015, 89, 99101 (in Chinese with English abstract).
[15] Yuan, X.J., Lin, S.H., Liu, Q., et al. Lacustrine fine-grained sedimentary features and organic-rich shale distribution pattern: $A$ case study of Chang 7 Member of Triassic Yanchang Formation in Ordos Basin, NW China. Petroleum Exploration \& Development, 2015, 42, 37-47.

[16] Wang, X., Zhang, L., Li, Z., et al. Pore type classification scheme for continental Yanchang shale in Ordos Basin and its geological significance. Oil \& Gas Geology, 2016, 37, 1-7 (in Chinese with English abstract).

[17] Er, C., Li, Y.Y., Zhao, J.Z., et al. Pore formation and occurrence in the organic-rich shales of the Triassic Chang-7 Member, Yanchang Formation, Ordos Basin, China. Natural Gas Geoscience, 2016, 1, 435-444.

[18] Jiang, C., Cheng, Y., Fan, B., et al. Progress in and challenges to geologic research of terrestrial shale in China: A case study from the $7^{\text {th }}$ member of the Upper Triassic Yanchang Fm in the Yanchang exploration block, Ordos Basin. Natural Gas Industry, 2014, 34, 27-33 (in Chinese with English abstract).

[19] Rushworth, S.W., Geochemical Evaluation of the Bakken Shale in the Williston Basin: Implications for Migration in Fractured Shale Plays. ABSTRACT. AAPG Bulletin, 1994, 78

[20] Vol, N., Retention and transport of a hydrocarbon in a silt. Géotechnique, 2003, 53, 83-91.

[21] Zhang, T., Ellis, G.S., Ruppel, S.C., et al. Effect of organic-matter type and thermal maturity on methane adsorption in shale-gas systems. Organic Geochemistry, 2012, 47, 120-131.

[22] Sun, L., Tuo, J., Zhang, M., et al. Formation and development of the pore structure in Chang 7 member oil-shale from Ordos Basin during organic matter evolution induced by hydrous pyrolysis. Fuel, 2015, 158, 549-557.

[23] Schmidt, R., Hansen, E.W., Stoecker, M., et al. Pore Size Determination of MCM-51 Mesoporous Materials by means of $1 \mathrm{H}$ NMR Spectroscopy, N2 adsorption, and HREM. A Preliminary Study. Journal of the American Chemical Society, 1995, 117, 4049-4056.

[24] Suzuki, M., Sakoda, A., Gas adsorption on activated carbons with size distribution of micropores. Journal of Chemical Engineering of Japan, 2006, 15, 279-285.

[25] Zhang, T.W., Wang, X.Z., Sun, X., et al. Effects of Oil and Water on Mudrock Pore Size Distribution and Pore-Scale Fluid Distribution. AAPG 2016 Annual Convention and Exhibition. Calgary, Alberta, Canada, 2016.

[26] Currey, J.D., The effect of porosity and mineral content on the Young's modulus of elasticity of compact bone. Journal of Biomechanics, 1988, 21, 131-139.

[27] Li, Z., Hu, J., Structural evolution and distribution of paleokarst reservoirs in the Ordos Basin. Oil \& Gas Geology, 2010, 31, 640639 (in Chinese with English abstract).

[28] Wang, Y., Xu, J., Mei, C., Chemical and mechanical properties of brittle fractured mud shale. Journal of Oil \& Gas Technology, 2011, 33, 104-108 (in Chinese with English abstract). 